University of Nebraska - Lincoln

DigitalCommons@University of Nebraska - Lincoln

HISTORICAL WETLANDS IN OREGON'S WILLAMETTE VALLEY: IMPLICATIONS FOR RESTORATION OF WINTER WATERBIRD HABITAT

Oriane W. Taft

Oregon State University

Susan M. Haig

U.S.G.S., Susan_Haig@usgs.gov

Follow this and additional works at: https://digitalcommons.unl.edu/usgsstaffpub

Taft, Oriane W. and Haig, Susan M., "HISTORICAL WETLANDS IN OREGON'S WILLAMETTE VALLEY: IMPLICATIONS FOR RESTORATION OF WINTER WATERBIRD HABITAT" (2003). USGS Staff -- Published Research. 694.

https://digitalcommons.unl.edu/usgsstaffpub/694

This Article is brought to you for free and open access by the US Geological Survey at DigitalCommons@University of Nebraska - Lincoln. It has been accepted for inclusion in USGS Staff -- Published Research by an authorized administrator of DigitalCommons@University of Nebraska - Lincoln. 


\title{
HISTORICAL WETLANDS IN OREGON'S WILLAMETTE VALLEY: IMPLICATIONS FOR RESTORATION OF WINTER WATERBIRD HABITAT
}

\author{
Oriane W. Taft ${ }^{1,2}$ and Susan M. Haig ${ }^{1}$ \\ ${ }^{1}$ USGS Forest and Rangeland Ecosystem Science Center \\ 3200 SW Jefferson Way \\ Corvallis, Oregon, USA 97331 \\ E-mail: Oriane_Taft@usgs.gov \\ ${ }^{2}$ Department of Fisheries and Wildlife \\ 104 Nash Hall \\ Oregon State University \\ Corvallis, Oregon, USA 97331
}

\begin{abstract}
Before agricultural expansion in the $19^{\text {th }}$ century, river valleys of North America supported expanses of wetland habitat. In restoring these landscapes, it is important to understand their historical condition and biological function. Synthesizing historical primary accounts (from explorers, travelers, settlers, and farmers) with contemporary knowledge of these wetland systems, we developed a profile of the wetlands and their use by nonbreeding waterbirds (e.g., waterfowl, wading birds, and shorebirds) within the Willamette Valley, Oregon, ca. 1840. We found evidence for three types of wetlands used by non-breeding waterbirds in fall, winter, and spring: emergent wetlands, riverine wetlands, and wetland prairie. The most extensive wetland type was wetland prairie, which functioned as fall/winter habitat for waterbirds, but only while native Kalapuyans managed the region with fire. Since the mid-1800s, four species, in particular, have decreased their use of the Willamette Valley: trumpeter swan (Cygnus buccinator), snow goose (Chen caerulescens), sandhill crane (Grus canadensis), and long-billed curlew (Numenius americanus). Information suggests that ca. 1840, waterbirds and their habitats were more abundant in the Willamette Valley than today. Restoration of the Willamette Valley landscape is warranted, and today's agricultural wetlands-former wetland prairie—-hold highest restoration potential.
\end{abstract}

Key Words: agricultural landscape, fire, historical wetlands, Kalapuya, land use, Oregon, shorebirds, wading birds, waterfowl, wetland loss, wetland prairie, wetland restoration, Willamette Valley

\section{INTRODUCTION}

Conversion of river valleys into agricultural landscapes accounts for the earliest and most profound loss of North American wetlands (Dahl 1990, Vileisis 1997, Mitsch and Gosselink 2000). The most vulnerable river valleys were characterized by open wet prairies and wide river floodplains. These features made them fertile farmland and facilitated their conversion into agricultural land by Euro-American settlers in the 1800s (Robbins 1997, Vileisis 1997, Nelson et al. 1998). Moreover, the extensive and spatially-uniform nature of agricultural settlement resulted in loss of these wetlands on a landscape scale (Maizel et al. 1998).

In the last few decades, there has been an increased recognition of wetland loss ( $>50 \%$ for many countries), the valuable functions of wetland ecosystems (e.g., flood control, water quality, wildlife habitat), the decline of numerous migratory waterbirds (Orders An- seriformes, Charadriiformes, Ciconiiformes, Gruiformes) and other wetland-dependant species, and the importance of conservation and restoration efforts at large spatial scales (Smith et al. 1989, National Research Council 1992, USFWS and CWS 1994, Mitsch and Gosselink 2000, Brown et al. 2001). As a result, many agencies are beginning to acknowledge the need to design and implement region-wide wetland restoration and wildlife conservation plans for agricultural river valleys in North America.

Successful restoration efforts rely on knowledge of the ecological condition of landscapes prior to European settlement (National Research Council 1992, Sisk 1998). For waterbird conservation, knowledge of the extent, spatial distribution, condition, and use of historic habitat provides insight regarding the relative importance of restoring wetlands in a region, effective spatial locations for restoration, and manipulations needed to emulate historic functions of wetland habitat. Although we can deduce the location of historic 
wetland sites from hydric soils data, inferring their biological characteristics and the diversity and abundance of waterbirds that used them requires historical research.

For many pioneers in the 1840 s, the Willamette Valley of Oregon was viewed as a paradise (Gibson 1985, Boag 1992, Robbins 1997). The Willamette Valley ("Valley") would undergo a substantial transition in land use since then, impacting native wetlands and other habitats (Gibson 1985, Robbins 1997). Today, remaining wetlands are primarily dispersed among small urban remnant wetlands, a few duck hunting clubs, four state and federal wildlife refuges, and hundreds of scattered agricultural wetlands. Unlike refuge wetlands, however, agricultural wetlands receive no formal protection. Collectively, these wetlands annually support at least 200,000 waterfowl and 40,000 or more shorebirds in winter and an unknown number of migrants in spring and fall (Johnson 1993, Gilligan et al. 1994, Nehls 1994, Sanzenbacher and Haig 2002 a,b, Robert Trost pers. comm.).

With large estimates for Valley-wide wetland losses and conversions (Hulse et al. 1998, Daggett et al. 1998, Christy et al. 2000) and continued yearly loss of habitat (Bernert et al. 1999), local and federal agencies and coalitions recognize the need to protect and restore Valley wetlands (Good and Sawyer 1998, Drut and Buchanan 2000, Morlan 2000, Oregon Wetlands Joint Venture 2001, Willamette Restoration Initiative 2001). However, the historical importance of these habitats to waterbirds and the impact of land-use change on waterbird populations have not been considered fully. We investigated the historical Willamette Valley at the time of early Euro-American settlement (ca. 1840). Our objectives were to deduce 1) the nature of historical wetland habitat suitable for waterbirds, 2) the spatial extent of these wetlands, and 3) their historical use during the non-breeding season (fall, winter, spring) by waterbirds. In addition, we present the history of changes to Valley wetlands and waterbird use.

\section{STUDY AREA}

The historical landscape of the Willamette Valley is a $9100 \mathrm{~km}^{2}$ area of lowland plains within the Willamette Basin of western Oregon, varying in width from about 20 to $60 \mathrm{~km}$, and covering a north-south length from Portland to Eugene of roughly $290 \mathrm{~km}$ (Benner and Sedell 1997, Hulse et al. 1998). The prominent hydrologic feature of the Valley is the northerly-flowing Willamette River and its 13 major tributaries, which drain 29,000 $\mathrm{km}^{2}$ (Gregory et al. 1998). The climate of this region is cool Mediterranean, with an average annual rainfall of $100-125 \mathrm{~cm}, 75 \%$ of it fall- ing between October and March (Jackson and Kimerling 1993). Average temperatures range from $1^{\circ} \mathrm{C}$ in January to $30^{\circ} \mathrm{C}$ in July (Oetter et al. 2000). The Valley includes two distinct topographic sub-ecoregions: 1) Willamette River and Tributaries Gallery Forestthe river, tributaries and associated bottomland forests within the floodplain and 2) Prairie Terrace-a flat fluvial terrace upslope of the bottomland floodplain (Clark et al. 1991, Pater et al. 1997). Today, lands in these regions grow a variety of crops, including grass seed, vegetable crops, fruit orchards, nursery and greenhouse stock, peppermint, and Christmas trees; grass seed fields are most prevalent (Hulse et al. 1998, Oetter el al. 2000). Currently, 70\% of Oregon's population lives in the Valley (Hulse et al. 1998).

\section{METHODS}

Although waterbirds as a group are associated with a wide variety of aquatic habitats, we looked for information on shallow-wetland species only, namely shorebirds (order Charadriiformes), dabbling ducks, geese, and swans (order Anseriformes), wading birds (order Ciconiiformes), and cranes (order Gruiformes). We did not consider certain cryptic species (e.g., American bittern Botaurus lentiginosus Rackett, rail spp.) that may have been common, but too inconspicuous to provide historical information. Within each of these groups, we searched for information on 21 species that presently winter and/or migrate through the Valley, plus four species that were formerly common but presently uncommon or even rare: trumpeter swan (Cygnus buccinator Ord), snow goose (Chen caerulescens Linnaeus), sandhill crane (Grus canadensis Linnaeus), and long-billed curlew (Numenius americanus Bechstein) (Gabrielson and Jewett 1940, Gilligan et al. 1994, Nehls 1994, Marshall et al. 2001).

Waterbirds generally feed in wetlands with features that maximize the abundance and accessibility of their foods, such as seeds (primarily dabbling ducks), new shoots of wetland plants (geese), tubers and rhizomes (geese, swans), and aquatic invertebrates (shorebirds and waterfowl) (Fredrickson and Reid 1986, Helmers 1991). These features include saturated or shallowly flooded $(<25 \mathrm{~cm})$ substrates (e.g., for dabbling ducks and shorebirds) that are relatively open with soft sediments (e.g., unvegetated mudflats for shorebirds) or covered with new, short grass or wetland plant shoots (e.g., for grazing waterfowl) (Colwell and Oring 1988, Ehrlich et al. 1988, Hands et al. 1991, Baldassarre and Bolen 1994). Consequently, to understand the nature of Valley wetlands for waterbirds, we sought historical information on degree of saturation/flooding and vegetative structure of Valley habitats.

We searched the literature beginning with Lewis 
and Clark's 1805-06 expedition to the Columbia River (when the Willamette River was first described; Perrine 1924), but we focused on the period 1820-1880, the years of Euro-American exploration and settlement of the Willamette Valley (Robbins 1997). Primary sources included fur trapper's journals, explorer/naturalist's logs, missionary writings, early settler-farmer diaries, promotionist's reports, and government documents. Secondary sources included habitat maps, geomorphology studies, anthropological research, and prior work on the historical Willamette River and its floodplain.

\section{RESULTS AND DISCUSSION}

\section{Historical Wetlands}

Christy et al. (2000) reconstructed a map of historical (ca. 1850) Willamette Valley land cover using data from General Land Office (GLO) surveys (e.g., Nelson et al. 1998) and other sources (e.g., Soil Survey Geographic (SSURGO) database (USDA 2000)). We combined classes described by Christy et al. (2000) into wetland categories important to waterbirds following Cowardin et al. (1979) terminology. These were emergent wetland (i.e., permanent, semi-permanent, or seasonally flooded emergent marsh and aquatic bed according to Cowardin et al. (1979)), riverine wetland (i.e., emergent, scrub-shrub, forested and open water wetlands and sloughs associated with the river floodplain), and wetland prairie (i.e., emergent seasonal wet grassland, which generally occurs on poorly drained flat to gently sloping lowland soils (Wilson 1998)). Wetland prairie was most extensive at 121,488 ha (Christy et al. 2000; Figure 1). In wetland prairie, poor drainage and low evaporation allow winter precipitation to accumulate, resulting in shallow, standing water (Finley 1995, Wilson 1998). Coverage for riverine wetlands was not calculated, but the estimate of 117,917 ha by Christy et al. (2000) for total "riparian and wetland forest" plus "open water" (rivers, sloughs, beaver ponds, lakes) illustrates the potential of this habitat. Emergent wetlands (3,599 ha) comprised a small fraction of total wetland habitat.

Emergent Wetlands. The largest examples of this wetland type were located in the Tualatin Basin (Wapato Lake) and near present-day Salem (Lake Labish; Figure 1; Henderson et al. 1916, Scott 1923, Christy et al. 2000). Between the 1830s and 1890s, observers mentioned in passing habitats that were likely emergent wetlands (Hines 1850, Nash 1882, Henry 1897, Scott 1923, Ellison 1932). Other emergent wetlands were associated with the river or tributary streams and maintained by river overflow and a higher water table
(Sedell and Froggatt 1984, Holland 1994, Gregory et al. 1998).

Riverine Wetlands. Historically, the winter volume of the Willamette River dispersed across its 1.5- to 3.5km-wide floodplain (Benner and Sedell 1997, Miller 1999). This active floodplain was broadest in the southern Valley where the alluvium was more gentlysloping (Sedell and Froggatt 1984). As a result, riverine wetlands were historically more numerous in the southern Valley. There were numerous floodplain tributaries draining the upland terrace and foothills (Benner and Sedell 1997). Dynamic river processes (high water events, gravel movement, large wood recruitment, sediment erosion and deposition) maintained extensive off-channel habitats-side channels, alcoves, sloughs, shallow lakes, and linear ponds (Sedell and Froggatt 1984, Benner and Sedell 1997, Landers et al. 2002). Prior to trapping in the early 1800 s, beaver (Castor canadensis Kuhl) also contributed to this complexity by ponding water (Sedell and Froggatt 1984, Benner and Sedell 1997, Robbins 1997). Snags and wood jams created slackwater pools and trapped organic debris. Floods were relatively frequent and played an important role in connecting the active river channel to the floodplain (Benner and Sedell 1997, Miller 1999). Flooding would also increase area of temporary flooded lowlands (Perrine 1924).

These processes resulted in an extensive surface area of shallow riverine shoreline with slow-moving or stagnant waters (Benner and Sedell 1997, Hulse et al. 1998). Such habitat would be of value to foraging and resting waterbirds, especially waterfowl and large wading birds (family Ardeidae). Side channels created islands within the floodplain (Gregory et al. 1998, Landers et al. 2002), which along with floodwater scouring, provided open (unvegetated) roosting habitat for waterbirds, especially shorebirds. Finally, the floodplain supported a dense riparian forest (Sedell and Froggatt 1984, Gregory et al. 1998, Hulse et al. 1998) whose organic material provided nutrients and substrates necessary to sustain river invertebrates (Sedell and Froggatt 1984).

Between 1811 and 1852, observers referred to the floodplain surrounding the river as "swampy" with "low ravines or sloughs overflowed with water" in late-fall and winter (Lee 1916, Kendall 1935, Franchere 1954, Palmer 1983). Moreover, many remarked on the regularity with which the river level would rise temporarily with winter rains to overflow into surrounding bottomlands (Hines 1850, Mills 1882, Henry 1897, Wilkes 1911, Howison 1913, Gary 1923, Ellison 1932, Wyeth 1969, Farnham 1977, Palmer 1983, Clyman 1984). Riverine wetlands persisted through spring migration as river overflow from spring snowmelt 


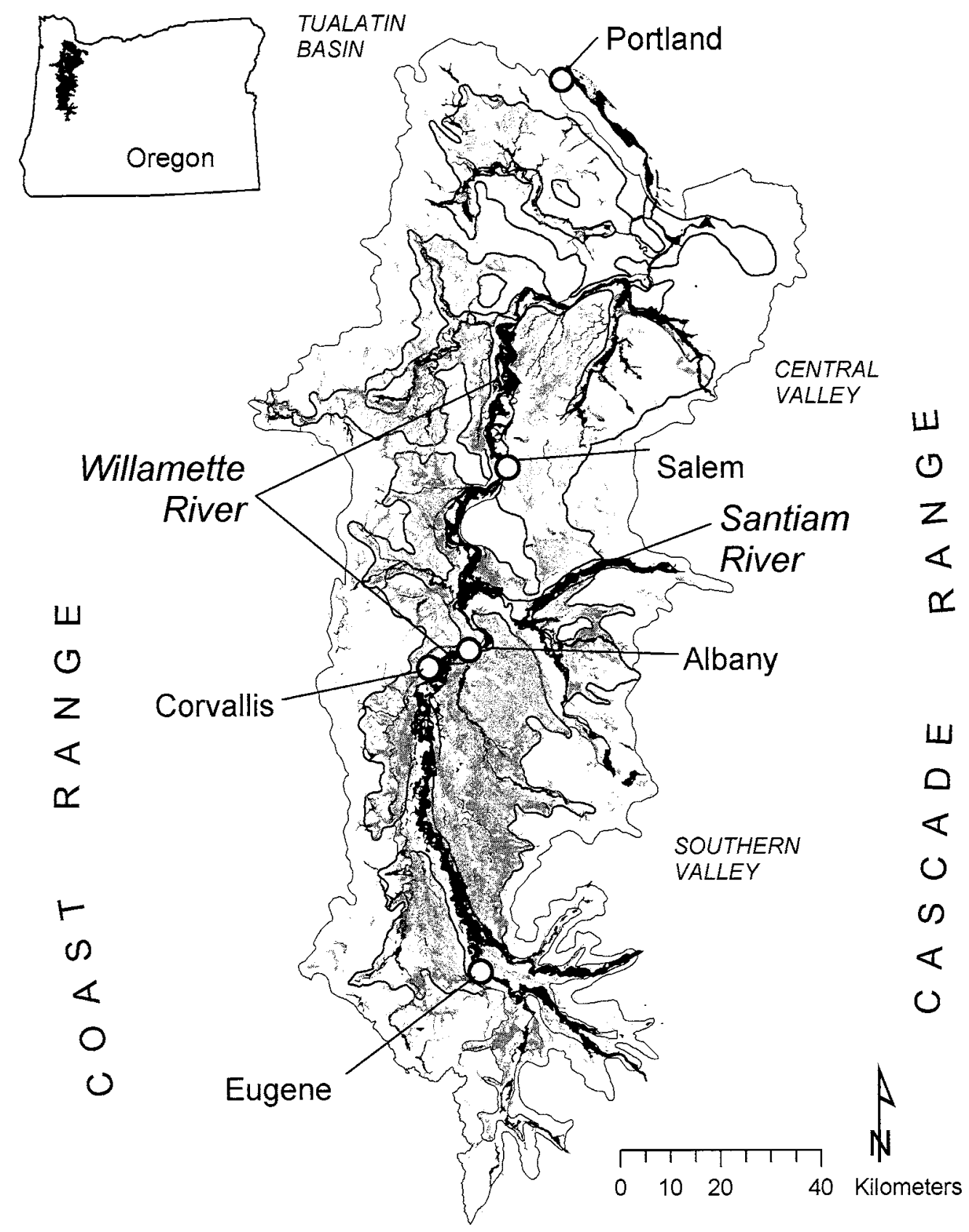

Figure 1. Historical (ca. 1850) wetland habitats of the Willamette Valley, Oregon, with wetland prairie shown in gray and riparian/wetland forest (locations of probable riverine wetlands) shown in black (modified from Christy et al. 2000). Emergent wetlands were too scarce to display at this scale. Although not considered part of the Willamette Valley lowlands, the Valley Foothills sub-ecoregion is displayed surrounding the Prairie Terrace and the Willamette River and Tributaries Gallery Forest sub-ecoregions of the Valley lowland proper (Clark et al. 1991, Pater et al. 1997).

(Hines 1850, Victor 1872, Mills 1882, Lee 1916, Gary 1923, Parker 1967).

Wetland Prairie. Historical accounts from the 1800s and more recent analyses indicate that open prairie was the dominant feature of the Valley before settlement (Minto 1908, Douglas 1959, Habeck 1961, Johannessen et al. 1971, Farnham 1977, Clyman 1984). Given the distribution of hydric soils across the prairie terrace
(Parsons et al. 1970, Daggett et al. 1998), roughly half of the Valley prairie was wetland (Hulse et al. 1998, Figure 1). Wet prairie lands were most extensive and continuous south of the Santiam River (between Albany and Eugene), averaging $32 \mathrm{~km}$ in width. North of this, wetland prairie was more common west of the Willamette River but patchily distributed east of the river (Bowen 1978, Holland 1994, Figure 1). Common 
wet prairie plant species included tufted hair-grass (Deschampsia cespitosa Linnaeus) and camas ( $\mathrm{Ca}$ massia quamish Pursh).

The combination of aboriginal fire and ponding from winter rainfall likely shaped the Valley wetland prairie into valuable habitat for many waterbirds. In summer and autumn, the indigenous Kalapuya set fire to prairie vegetation to promote maintenance of food plants, facilitate crop harvesting, and aid in hunting (Zenk 1976, Boyd 1986; see Whitlock and Knox (2002) for a contrary view on the role of aboriginal fire in shaping Valley vegetation). Because fires took place annually, fuel buildup was low and burns were of low intensity (Boyd 1986). Burning was spatially extensive (e.g., Hines 1850, Wilkes 1911, Lee 1916, Scott 1923, Douglas 1959, McLeod 1961, Farnham 1977, Clyman 1984), as also indicated by the pre-contact size of the Kalapuya population (ca. 13,000 people; Boyd 1986) and their dispersed distribution (Poesch 1961). Moreover, the most prominent plant component of the Kalapuya diet was camas bulbs (Zenk 1976, Boyd 1986) that were abundant via reduction of competing woody plants through fire (Wilson 1998).

After fire, birds could access the substrate for food and increase their vigilance for predators. Defoliation from fire was evident from historical accounts in the early 1800 s. Many commented on the difficulty in finding fodder for horses (Hines 1850, Wilkes 1911, Lee 1916, Scott 1923, Douglas 1959, McLeod 1961, Farnham 1977, Clyman 1984), and others observed that vegetation of burned prairies was only $7 \mathrm{~cm}$ high in November (Clyman 1984) and $15 \mathrm{~cm}$ tall by February (Ball 1833). Moreover, the horizontal structure of prairies was relatively open historically, as mature plants were segregated spatially, with unvegetated spaces between them (Wilson 1998).

Exposed prairie soils would not be attractive to most waterbirds unless saturated or flooded. Evidence for ponding of wetland prairies in the Valley comes from a number of historical accounts. In 1834, trapper John Work reported on prairie lands that were currently or previously inundated from winter rains, mostly in the south Valley (Scott 1923). Prior to the 1880s, many commented on the prairie in winter and spring as "wet and muddy," "covered with water," "too wet for the plow," "percolating quicksands," and in general poorly-drained (Victor 1872, Murphy 1879, Nash 1882, Shafer 1909, Wilkes 1911, Henderson et al. 1916, Hancock 1927, McLeod 1961, Parker 1967, Palmer 1983, Clyman 1984). Consequently, early settlement occurred on the upland prairie-woodland edges of the Valley (Kendall 1935, Bowen 1978, Boag 1992, Bunting 1993). Prevalence of standing winter water was further supported by the springtime presence of mosquitos (Gary 1923, Douglas 1959) and outbreaks of malaria among the Kalapuya (Boyd 1975).

Wetland prairies potentially held valuable food resources for waterbirds. Among common native wet prairie plants identified for the Valley (Wilson 1998), spikerushes (Eleocharis spp.), sedges (Carex spp.), wild barley (Hordeum spp.), and buttercup (Ranunculus spp.) have been found in waterfowl diets (Martin and Uhler 1939). For grazing species like geese and American wigeon (Anas americana Gmelin), new forbs and shoots from grasses would have presented browse. Invertebrates important to shorebirds and dabbling ducks (e.g., oligochaetes, diptera larvae, and other aquatic insects) are widespread in their distribution among wetland prairies (Coupland 1979, Pennak 1989).

Contemporary research indicates that the combined effects of burning and flooding can increase the abundance and accessibility of food in wetlands (Lynch 1941, de Szalay and Resh 1997), as well as use by waterbirds (Schlichtemeier 1967, Vogl 1973, Kantrud 1986, Stone 1994). Fire has been used commonly as a waterbird management technique in some marshes and ricefields in North America (Ward 1968, Rutkosky 1978, Kantrud 1986, Weller 1987, Fredrickson and Laubhan 1994, Brouder and Hill 1995, Gabrey et al. 1999). Burning fertilizes and may increase protein content of regenerating plants (Singh and Joshi 1979, Smith et al. 1984, Weller 1987). For invertebrates, fire and standing water at mild temperatures (at least $4^{\circ} \mathrm{C}$ ) accelerate decomposition of organic debris by microbes (Kantrud 1986, Brouder and Hill 1995). Finally, fire and flooding aids waterbird access to food (Brouder and Hill 1995).

The Kalapuya subsisted primarily on a diverse assemblage of wild plants and, secondarily, on wild game (Boyd 1986, Boag 1992), including waterfowl harvested during migration and in winter (Jacobs 1945, Zenk 1976). In addition to burning for immediate effects (e.g., to harvest tarweed and collect grasshoppers), they burned for long-term goals (e.g., to promote the continued growth of camas; Boyd 1986), which allows for the possibility that one long-term goal was to maintain habitat for waterbirds. That the Kalapuya may have used fire to manage for winter waterbirds is also supported by early settler John Minto (1908).

\section{Use By Waterbirds}

The most valuable accounts of waterbird use of wetlands are from fur trappers of the 1820-30s because they traversed the Valley in winter as well as fall. Accounts generated from early zoological expeditions (e.g., Newberry 1857, Peale 1858) were less thorough, as they only catalogued birds in fall during migration. 
Resources were most often recorded in terms of their economic importance (Bunting 1993, Robbins 1997). Thus, birds that were large, gregarious, and hunted more easily made their way into journal entries, while the small, inconspicuous, and non-hunted likely escaped observation. Travels for scientific inventory and other purposes were carried out in fall, spring, and summer, whereas winter travel was avoided.

Most accounts only described a species' presence during a season. Fewer described relative abundances and associated habitats. Among wetland types, there are generally more accounts of waterbirds using wetland prairie. Given that the prairie terrace and rivers were similarly traversed by Euro-Americans (Boag 1992, Robbins 1997), one could interpret this to indicate that waterbirds primarily used wetland prairies for feeding and roosting. We found few accounts of birds using what we thought to be emergent wetlands, perhaps because of their low relative abundance or because of settler's general avoidance of marshes (Robbins 1997).

Waterfowl. Waterfowl were the most widely noticed group. Many species of swans, geese, and dabbling ducks were considered abundant during migration and winter (Howison 1913, Clyman 1984; Table 1). Of hunted waterfowl, the Kalapuya recognized one swan, three geese, and three duck species (Jacobs 1945, Zenk 1976). Among Euro-Americans, most swans were thought to be tundra swans (see Table 1 for scientific names), although it is possible that some were trumpeter swans. Although common but relatively rare compared to other waterbirds during migration (Newberry 1857, Johnson 1880), there is no direct information on the occurrence of trumpeter swans in winter. Snow geese were widespread and abundant during migration and winter (Hartlaub 1852, Douglas 1959). In fall, Peale (1858) commented on the large numbers of snow geese roosting with white-fronted geese and cranes on wetland prairie. Kalapuya recognized snow geese as distinct from other waterfowl, and they were among waterfowl species hunted regularly (Zenk 1976). Among dabbling ducks, northern shoveler and gadwall seemed to be less abundant than other species.

Early accounts indicate that waterfowl were associated with all three wetland types. On emergent wetlands, Peale (1858), Minto (1908), and Clyman (1984) observed abundant waterfowl during fall. In winter, Prill (1895) observed several species of geese on the ' "marshes of the valley.' Of greater emphasis was the degree to which riverine wetlands were frequented by geese (Wilkes 1911, Farnham 1977) and dabbling ducks (Johnson 1880, Wilkes 1911, Farnham 1977) during migration, and by all waterfowl, including swans, in winter (Prill 1895, Minto 1908, Parker 1967,
Clyman 1984). We found additional observations of geese and dabbling ducks using riverine wetlands, but the particular non-breeding seasons were not specified (Murphy 1879, Nash 1882, Pope 1896). Nash (1882) observed geese roosting on sand and gravel bars of the river during fall. Lastly, wetland prairies were used extensively by foraging and roosting waterfowl. Throughout the early 1800s, swans and geese were commonly noticed feeding and roosting on the "moist prairies" in migration (Peale 1858, Douglas 1959, Clyman 1984), with dabbling ducks joining them on "overflown lowlands" and "grasses of the damp lands" in winter (Allen 1848, Hartlaub 1852, Minto 1908, Howison 1913, Douglas 1959, Clyman 1984).

Wading Birds and Cranes. Among wading birds, herons and egrets were considered common in migration and winter (Table 1). Newberry (1857) and Clyman (1984) commented that great blue heron were abundant in the 1840-1850s. The Kalapuya recognized this species as distinct from other wading birds (Zenk 1976). We found no information on the association of wading birds with wetland habitat types. During the non-breeding season, wading birds are not gregarious, typically foraging alone or in small groups (Ehrlich et al. 1988). This trait may explain why early observers did not notice these species more often.

Sandhill cranes were among the waterbird species recognized by the Kalapuya (Zenk 1976), but there is no indication they were hunted. Most accounts of the 1800s speak to the regularity with which cranes were seen during autumn (Table 1), but two accounts assert that they were also common in the Valley in winter (Hartlaub 1852, Minto 1908). Most spoke of the sandhill crane's affinity to wet prairie (Hartlaub 1852, Clyman 1984), but Minto (1908) noted that cranes wintered in great numbers on all three wetland types. Peale (1858) wrote that migrant cranes prefer "moist open grounds, and roost generally on small sand-bars in the rivers."

Shorebirds. There are not as many early (pre-1860) references to shorebirds as there are to waterfowl (Table 1). Accounts are mostly of the larger-bodied shorebirds, perhaps because only large species were hunted (Anonymous 1913). Killdeer, common snipe, and long-billed curlew were the most commonly noted species (Table 1). The only early record found for dunlin was from Johnson (1880), and he commented that they were seen only occasionally during migration. As popular usage of terms was loose, some accounts of snipe may have been of long-billed dowitchers or other shorebirds. Indeed, an early common name for longbilled dowitcher was "red-breasted snipe"' (Newberry 1857) and "jack snipe" (Takekawa and Warnock 2000). The Kalapuya recognized at least three shore- 
bird species, one of which was presumed to be common snipe (Zenk 1976).

Some shorebird species were observed on small "ponds with vegetation" or "wet boggy localities," which we suppose were emergent wetlands (Pope 1896, Minto 1908, Clyman 1984). Peale (1858) collected a red-necked phalarope on the Willamette River, and Minto (1908) included shorebirds among the waterbirds observed in winter on riverine sloughs. On wetland prairie, Peale (1858) observed shorebirds during migration, and Minto (1908) and Clyman (1984) observed them in winter.

Long-billed curlew were observed on small "ponds with vegetation" (Minto 1908), which we presume were emergent wetlands. Minto (1908) included curlew among waterbirds observed in winter on riverine sloughs. On wetland prairie, Peale (1858) remarked that curlew were "quite common on the prairies of Oregon" during fall, and Minto (1908) found them among the waterbirds that "wintered on the grasses and roots of the damp lands of the valleys." Among shorebirds described by the Kalapuya, one was characterized as "a bird somewhat resembling the crane, but smaller, little, long-legged" (Zenk 1976). We speculate this was the long-billed curlew.

\section{Land-Use Changes}

Chronology and Consequences. Suppression of annual prairie burning was potentially the most overlooked of land-use changes to impact habitat, especially wetland prairie. Malaria left only 600 Kalapuya in the Valley by 1841 , and by the mid-1840s, immigrant settlers forced an end to widespread burning (Boyd 1986). Consequently, by 1850, the nature of wetland prairie had changed dramatically. Although the first homesteaders settled on upland dry prairie habitats that were naturally well-drained, by 1871, expansion of railroads on both sides of the river led to an extension of farming activities into the wetland prairie (Woodward et al. 1998). Wheat farming on the wetland prairie gradually diminished wet habitat. With recognition that these lands were too wet for farming, surface ditching became a major activity between 1860 and 1880 (Bunting 1993, Robbins 1997). By 1880, wheat production had increased from 7 to 176 million liters per year (Boag 1992, Robbins 1997). Surface ditching continued until the early 1900s, at which time, the state of Oregon advocated installation of tile drains as a superior means of draining wet prairie (Williams 1914, Oregon State Planning Board 1938). Thus, by the time burning came into practice again with grass seed farming in the 1940s (Svart 1970), much of the wetland prairie had been drained. Between the 1940s and 1970s, the Valley experienced another intensive effort to drain any remaining problematic areas (USDA Soil Conservation Service 1977).

Wheat farming also resulted in a number of changes to riverine wetlands once the Willamette River became a conduit for agricultural commerce (Sedell and Froggatt 1984, Benner and Sedell 1997). Changes to channel morphology to improve navigation altered natural processes that maintained riverine wetlands (Benner and Sedell 1997, Landers et al. 2002). Steamboats appeared on the river in 1850 (Woodward et al. 1998). Efforts to simplify the river system began in the 1870 s when the U.S. Army Corps of Engineers used cut-off dams and dredge spoils to isolate secondary channels and off-channel habitats from the mainstem (Sedell and Froggatt 1984, Benner and Sedell 1997). In-channel large wood was removed and revetments were constructed to constrain the main channel. With bottomland riparian forests felled and loss of secondary channels, off-channel habitats (e.g., sloughs, oxbows, swales, small depressions) adjacent to the river were more easily converted to farmland (Benner and Sedell 1997). These modifications continued to the 1940s (Robbins 1997). Along the $25-\mathrm{km}$ stretch between Harrisburg and the McKenzie River confluence, the Willamette provided $250 \mathrm{~km}$ of shoreline in 1854; by 1946 , only $82 \mathrm{~km}$ of shoreline remained (Sedell and Froggatt 1984). Between 1940 and 1980, dam construction to restrict flooding events (Hulse et al. 1998) further added to loss of riverine wetlands (Benner and Sedell 1997).

Loss of Valley wetlands undoubtedly impacted use by many waterbirds. Described by settler Minto (1908: 131), "the ditching to drain roadbeds, and drains for field crops and cultivated fruits ... have all tended to absorb the life-giving surface moisture .... and the general effect is that the Willamette Valley has ceased to be the home of the crane, curlew, gray plover, and even the snipe, as well as the ... wild duck." Hunting for sport and the plume market also decreased numbers of many waterbirds, especially larger shorebirds and wading birds (Finley 1909, Anonymous 1913, Storm 1941). Among species currently occurring in the Valley, trumpeter swan, snow geese, sandhill crane, and long-billed curlew are rare (Gilligan et al. 1994, Nehls 1994, Marshall et al. 2001). Trumpeter swan, snow geese, and long-billed curlew were considered scarce in the Valley as early as 1902 (Woodcock 1902). Gabrielson and Jewett (1940) considered all four species as rare by 1940 .

Estimates of Loss/Conversions of Wetlands Used by Waterbirds. Although estimates of wetland habitat loss and conversion are varied, they provide a general sense of the extent to which waterbird habitat has been compromised. Hulse et al. (1998) estimated 57\% loss 


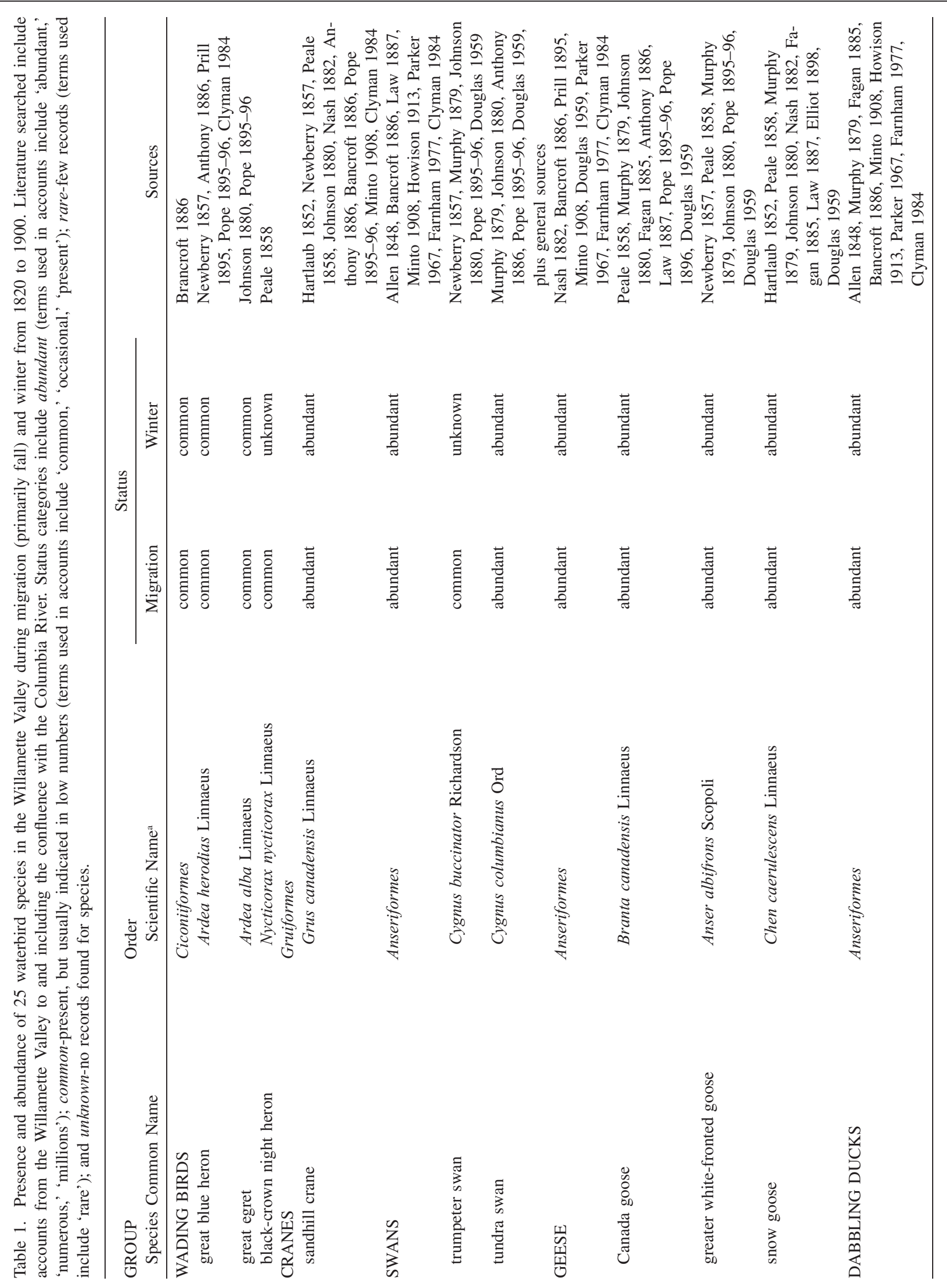




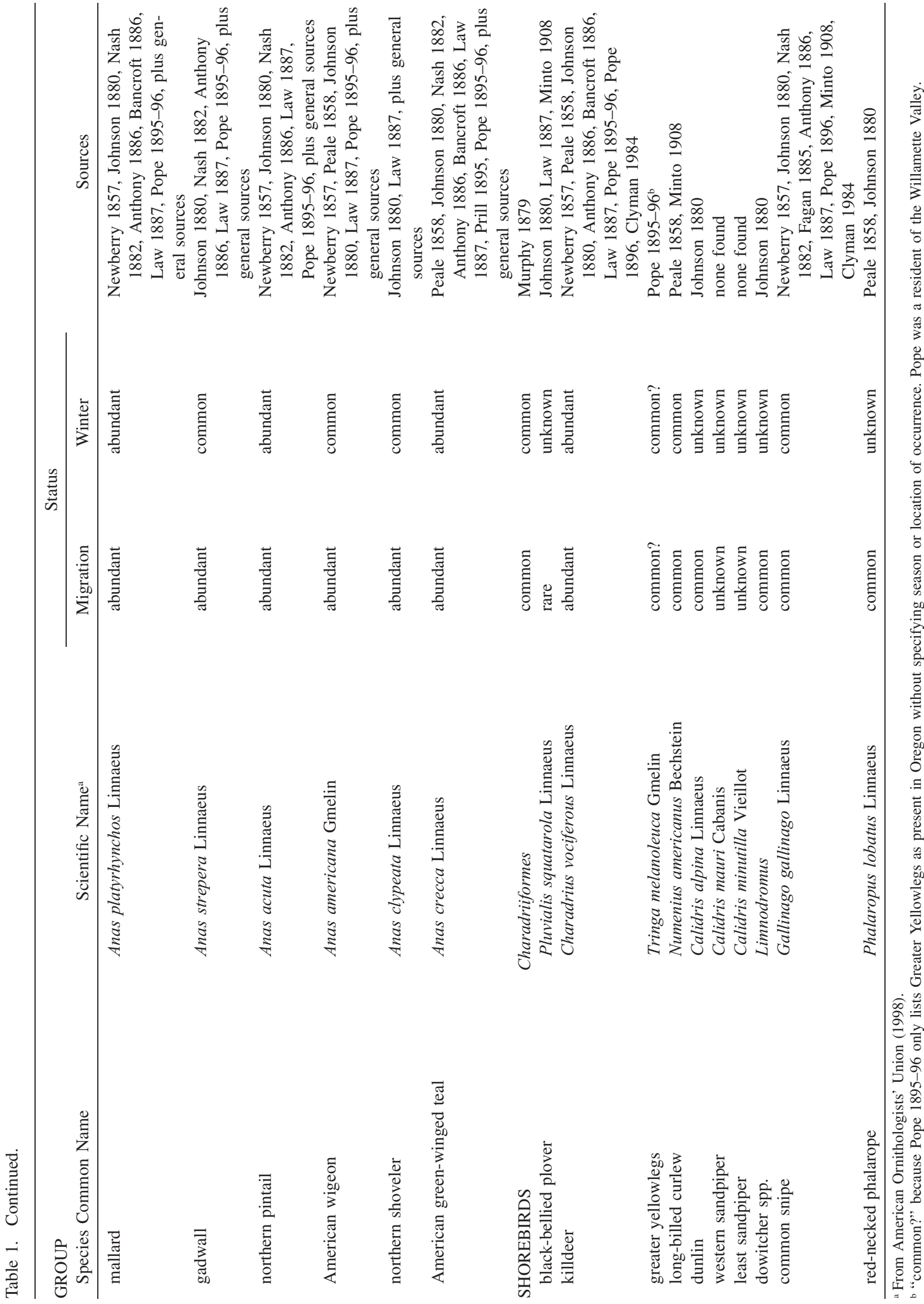


of emergent wetland habitat, $72 \%$ loss of bottomland forest, and $99 \%$ loss of native wetland prairie. For all wetland types combined (but not including most conversions to agricultural wetlands as extant habitat), Gabriel (1993) estimated a $41 \%$ loss/conversion of wetland habitat. Using the Daggett et al. (1998) estimate of 80,848 ha of extant non-agricultural wetlands and the Christy et al. (2000) estimate for historical wetlands, we hypothesize a $67 \%$ total loss/conversion of wetland habitat.

\section{Restoration Implications}

Western settlement and agricultural enterprise of the mid-1800s changed wetland landscapes elsewhere in the Pacific Flyway. Estuarine wetlands along the coasts of Washington (Puget Sound, Grays Harbor, Willapa Bay), Oregon (Columbia River and 21 smaller estuaries), and Northern California (Humboldt Bay) were diked and drained for farmland or urban development (Bortleson et al. 1980, Shapiro and Associates, Inc. 1980, Thomas 1983, Boulé and Bierly 1987). Wetland losses vary from 50 to $95 \%$ among these locales (Boulé and Bierly 1987). Further south, reclamation for agriculture, flood control, and development reduced wetland habitat by $75 \%$ (Klamath Basin, San Francisco Bay) to $94 \%$ (California's Central Valley; Akins 1970, Dennis and Marcus 1984). Thus, given the mobility of migratory waterbirds, negative trends in Valley bird use are likely in response to changes in local habitat availability and to loss of waterbird habitat throughout the flyway. Widespread loss of habitat and populations argues for local restoration of habitat wherever possible.

Understanding historical Valley wetlands and how they functioned for waterbirds provides insight on how to approach local restoration. Numerous agencies are currently involved in Valley wetland inventory, protection, mitigation, and regulation (i.e., Oregon Division of State Lands, U.S. Army Corps of Engineers, U.S. Environmental Protection Agency), as well as wetland creation and restoration (i.e., Oregon Department of Fish and Wildlife, USDA-Natural Resources Conservation Service, U.S. Fish and Wildlife Service). Moreover, two coalitions (Willamette Restoration Initiative, Pacific Northwest Ecosystem Research Consortium) have formed to find sustainable ways to stem further loss and restore habitats in the Valley, including wetlands (Hulse et al. 1998, Willamette Restoration Initiative 2001). However, these agencies and coalitions have focused on emergent wetlands or wetlands associated with the river floodplain. Although much of the former wetland prairie holds the greatest potential for restoration, it has not been factored into overall restoration plans.
Most of the former wetland prairie is now "agricultural wetland," palustrine emergent farmed wetlands that are seasonally flooded (Cowardin et al. 1979). These are cultivated lands where winter ponding temporarily persists, supporting hydrophytes if farming were discontinued (Daggett et al. 1998). Inventories estimate that agricultural wetlands account for at least half of the non-forested wetlands that remain (Daggett et al. 1998, Bernert et al. 1999). To some degree, plowed and newly-planted fields emulate historical fall-burned prairies, and where rainfall is allowed to collect on the field's surface, they somewhat mimic historical winter wetland prairies. These habitats are used extensively by waterbirds (Budeau 1992, Sanzenbacher and Haig 2002 a,b) but receive little regulatory protection (Morlan and Peters 1999). It is important to identify these wetlands during the rainy season, map their winter distribution (Taft et al. 2003 in press), and work with farmers to examine sustainable ways to enhance their function.

Finally, our findings speak to the potential importance of historic wetland prairie to waterbirds in other landscapes of North America. The east-west spread of agricultural cultivation from 1760 to the present explains why wet prairies are among North America's most endangered ecosystems (Samson and Knopf 1994, Noss et al. 1995, Prince 1997, Maizel et al. 1998). However, outside of the Prairie Pothole Region (i.e., the Dakotas, Minnesota, Saskatchewan, Manitoba), the historic value of wet prairie as migratory and wintering habitat for waterbirds has not been recognized. While many have recognized the value of historic palustrine wetlands in general (e.g., Smith et al. 1989), the value of the specific palustrine wetland type of wet prairie is rarely highlighted. Wet prairies of the river valleys of the Upper Mississippi states between the Missouri and Ohio Rivers (e.g., Illinois, Indiana, Ohio), the eastern Great Plains, and the Central Valley of California likely provided valuable migratory and wintering habitats for many waterbirds. These regions were characterized by river floodplains, vast wetland prairies, and meadows on poorly-drained flat lowlands (Prince 1997, Vileisis 1997). Aboriginal groups of these areas similarly used fire as a management tool (Barrett 1980, Boyd 1986, Kantrud et al. 1989, Askins 1997, Nelson et al. 1998), and burning accompanied by surface ponding potentially rendered them valuable foraging habitat for nonbreeding waterbirds. Like the Willamette Valley, early agricultural settlement resulted in the drainage of their prairies (Winsor 1987, Prince 1997, Nelson et al. 1998) and improved navigation and flood control disconnected rivers from their floodplains (Gregory et al. 1998). Recognition of the historic significance of these former wetland prairie 
landscapes should bring new resonance to the wetland restoration of agricultural landscapes for waterbirds.

\section{ACKNOWLEDGMENTS}

This work benefitted from discussions with K. Bierly, G. Grant, C. Henny, J. Jones, H. Huddleston, S. Kolar, J. Morlan, D. Oetter, L. Oring, D. Peters, W. Robbins, P. Sanzenbacher, and M. Taft. R. Jarvis, J. Morlan, and P. Sanzenbacher contributed comments on earlier drafts of the manuscript. We thank J. Christy and The Nature Conservancy for digital historical vegetation data contributing to Figure 1. We used G. Jobanek's (1997) "An Annotated Bibliography of Oregon Bird Literature Published Before 1935", (Oregon State University Press, Corvallis, OR, USA) as a resource for historical bird records. This study was funded by USGS Forest and Rangeland Ecosystem Science Center, U.S. Fish and Wildlife Service, Oregon Department of Fish and Wildlife, and Bureau of Land Management.

\section{LITERATURE CITED}

Akins, G. J. 1970. The effects of land use and land management on the wetlands of the upper Klamath Basin. M.S. Thesis. Western Washington State College, Bellingham, WA, USA.

Allen, A. J. 1848. Ten Years in Oregon. Mack, Andrus and Company, Ithaca, NY, USA.

American Ornithologists' Union. 1998. Check-list of North American Birds- the Species of Birds of North America from the Arctic through Panama, Including the West Indies and Hawaiian Islands, $7^{\text {th }}$ edition. Allen Press, Inc., Lawrence, KS, USA.

Anonymous. 1913. Shore bird season closes December 15. Oregon Sportsman 1:12.

Anthony, A. W. 1886. Field notes on the birds of Washington County, Oregon. Auk 3:161-172.

Askins, R. A. 1997. History of grasslands in the northeastern United States: implications for bird conservation. p. 119-136. In P. D. Vickery and P. W. Dunwiddie (eds.) Grasslands of Northeastern North America. Massachusetts Audubon Society, Lincoln, MA, USA.

Baldassarre, G. A. and E. G. Bolen. 1994. Waterfowl Ecology and Management. John Wiley and Sons, Inc., New York, NY, USA.

Ball, J. 1833. Unpublished letter of 2/22/33. Oregon Historical Society, Portland, OR, USA. Mss 195.

Bancroft, H. H. 1886. History of Oregon, volume 1. The History Company, San Francisco, CA, USA.

Barrett, S. W. 1980. Indians and fire. Western Wildlands 6:17-21.

Bellrose, F. C. 1978. Ducks, Geese and Swans of North America. Stackpole Books, Harrisburg, PA, USA.

Benner, P. A. and J. R. Sedell. 1997. Upper Willamette River landscape: a historic perspective. p. 23-47. In A. Laenen and D.A. Dunnette (eds.) River Quality: Dynamics and Restoration. Lewis Publishers, New York, NY, USA.

Bernert, J. A., J. M. Eilers, B. J. Eilers, E. Blok, S. G. Daggett, and K. F. Bierly. 1999. Recent wetlands trends (1981/82-1994) in the Willamette Valley, Oregon, USA. Wetlands 19:545-559.

Boag, P. G. 1992. Environment and Experience: Settlement Culture in Nineteenth-century Oregon. University of California Press, Berkeley, CA, USA.

Bortleson, G. C., M. J. Chrzastowske, and A. K. Helgerson. 1980. Historical changes of shoreline and wetland at eleven major deltas in the Puget Sound region, Washington. U.S. Geological Survey, Washington, DC, USA. Atlas No. HA-617.
Boulé, M. E. and K. F. Bierly. 1987. History of estuarine wetland development and alteration: what have we wrought? Northwest Environmental Journal 3:43-61.

Bowen, W. A. 1978. The Willamette Valley-Migration and Settlement on the Oregon Frontier. University of Washington Press, Seattle, WA, USA.

Boyd, R. 1986. Strategies of Indian burning in the Willamette Valley. Canadian Journal of Anthropology 5:65-86.

Boyd, R. 1975. Another look at the 'fever and ague' of western Oregon. Ethnohistory 22:135-154.

Brouder, S. M. and J. E. Hill. 1995. Winter flooding of ricelands provides waterfowl habitat. California Agriculture 49:58-64.

Brown, S., C. Hickey, B. Harrington, and R. Gill (eds.). 2001. The U.S. Shorebird Conservation Plan, $2^{\text {nd }}$ edition. Manomet Center for Conservation Sciences, Manomet, MA, USA.

Budeau, D. 1992. Wildlife use of agriculturally disturbed wetland sites in the Willamette Valley, Oregon. Oregon Fish and Wildlife Department, Salem, OR, USA.

Bunting, R. R. 1993. Landscaping the Pacific Northwest: a cultural and ecological mapping of the Douglas-fir region, 1778-1900. Ph.D. Dissertation. University of California, Davis, CA, USA.

Christy, J., E. Alverson, M. Dougherty, S. Kolar, L. Ashkenas, and P. Minear. 2000. Presettlement vegetation for the Willamette Valley, Oregon, version 4.0, compiled from records of the General Land Office Surveyors (c. 1850), Oregon Natural Heritage Program, Portland, OR, USA.

Clark, S. E., D. White, and A. L. Schaedel. 1991. Oregon, USA, ecological regions and subregions for water quality management. Environmental Management 15:847-856.

Clyman, J. 1984. Journal of a Mountain Man. Classics of the Fur Trade Series. Mountain Press Publishing Company, Missoula, MT, USA.

Colwell, M. A. and L. W. Oring. 1988. Habitat use by breeding and migrating shorebirds in southcentral Saskatchewan. Wilson Bulletin 100:554-566.

Coupland, R. T. 1979. The nature of grassland. p. 23-29. In R. T. Coupland (ed.) Grassland Ecosystems of the World: Analysis of Grasslands and Their Uses. International Biological Programme 18, Cambridge University Press, Cambridge, UK.

Cowardin, L. M., V. Carter, F. C. Golet, and E. T. LaRoe. 1979. Classification of wetlands and deepwater habitats of the United States. US Fish and Wildlife Service, Washington, DC, USA.

Daggett, S. G., M. E. Boulé, J. A. Bernert, J. M. Eilers, E. Blok, D. Peters, and J. Morlan. 1998. Wetland and land use changes in the Willamette Valley, Oregon: 1982 to 1994. Shapiro and Associates, Inc. Report to the Oregon Division of State Lands, Salem, OR, USA.

Dahl, T. E. 1990. Wetlands: losses in the Unites States 1780s to 1980s. U.S. Fish and Wildlife Service, Washington, DC, USA.

de Szalay, F. A. and V. H. Resh. 1997. Responses of wetland invertebrates and plants important in waterfowl diets to burning and mowing of emergent vegetation. Wetlands 17:149-156.

Dennis, N. B. and M. L. Marcus. 1984. Status and trends of California wetlands. Environmental Science Associates, Inc., San Francisco, CA, USA.

Douglas, D. 1959. Journal Kept by David Douglas During his Travels in North America, 1823-1827. Wesley and Son's, Antiquarian Press Ltd, New York, NY, USA.

Drut, M. S. and J. B. Buchanan. 2000. The U.S. Shorebird Conservation Plan: Northern Pacific Coast Regional Shorebird Management Plan. Manomet Center for Conservation Sciences, Manomet, MA, USA.

Ehrlich, P. R., D. S. Dobkin, and D. Wheye. 1988. The Birder's Handbook: a Field Guide to the Natural History of North American Birds. Simon and Schuster Inc., New York, NY, USA.

Elliot, D. G. 1898. The Wild Fowl of the United States and British Possessions or the Swan, Geese, Ducks, and Mergansers of North America. Francis P. Harper, New York, NY, USA.

Ellison, J. W. 1932. Diary of Maria Parsons Belshaw. Oregon Historical Quarterly 4:318-333.

Fagan, D. D. 1885. History of Benton County, Oregon. A.G. Welling, Portland, OR, USA.

Farnham, T. J. 1977. An 1839 Wagon Train Journal: Travels in the 
Great Western Prairies, the Anahuac and Rocky Mountains, and in the Oregon Territory, reprint from the 1843 edition. Greeley and McElrath, New York, NY, USA.

Finley, K. K. 1995. Hydrology and related soil features of three Willamette Valley wetland prairies. M.S. Thesis. Oregon State University, Corvallis, OR, USA.

Finley, W. L. 1909. Law enforcement in Oregon. Bird-Lore 11:188.

Franchere, G. 1954. A Voyage to the Northwest Coast of America, translation of original French edition. Lakeside Press, Chicago, IL, USA.

Fredrickson, L. H. and M. K. Laubhan. 1994. Managing wetlands for wildlife. p. 623-647. In T. A. Bookhout (ed.) Research and Management Techniques for Wildlife and Habitats. The Wildlife Society, Bethesda, MD, USA.

Fredrickson, L. H. and F. A. Reid. 1986. Wetland and riparian habitats: a nongame management overview. p. 59-96. In J. B. Hale, L. B. Best, and R. L. Clawson (eds.) Management of Nongame Wildlife in the Midwest: A Developing Art. North Central Section, The Wildlife Society, Grand Rapids, MO, USA.

Gabrey, S. W., A. D. Afton, and B. C. Wilson. 1999. Effects of winter burning and structural marsh management on vegetation and winter bird abundance in the Gulf Coast Chenier Plain, USA. Wetlands 19:594-606.

Gabriel, J. T. 1993. A modified synoptic analysis of the status of Oregon's Willamette Valley wetlands. Master's Degree Research Paper, Oregon State University, Corvallis, OR, USA.

Gabrielson, I. N. and S. G. Jewett. 1940. Birds of the Pacific Northwest, with Special Reference to Oregon. Dover Publications, Inc., New York, NY, USA.

Gary, G. 1923. Diary of Reverend George Gary. Oregon Historical Quarterly 24:269-333.

Gibson, J. R. 1985. Farming the Frontier: The Agricultural Opening of the Oregon Country, 1786-1846. University of Washington Press, Seattle, WA, USA.

Gilligan, J., D. Rogers, M. Smith, and A. Contreras (eds.). 1994. Birds of Oregon: Status and Distribution. Cinclus Publications, McMinnville, OR, USA.

Good, J. W. and C. B. Sawyer. 1998. Recommendations for a nonregulatory wetland restoration program for Oregon. Oregon Sea Grant, Corvallis, OR, USA.

Gregory, S. V., D. W. Hulse, D. H. Landers, and E. Whitelaw. 1998. Integration of biophysical and socioeconomic patterns in riparian restoration of large rivers. Hydrology in a Changing Environment $1: 231-247$.

Habeck, J. R. 1961. The original vegetation of the mid-Willamette Valley. Northwest Science 35:65-77.

Hancock, S. 1927. The Narrative of Samuel Hancock, 1845-1860. Robert M. McBride and Company, New York, NY, USA.

Hands, H. M., M. R. Ryan, and J. W. Smith. 1991. Migrant shorebird use of marsh, moist-soil, and flooded agricultural habitats. Wildlife Society Bulletin 19:457-464.

Hartlaub, G. 1852. R. Titian Peale's Vögel der “'United States Exploring Expedition." Archiv für Naturgeschichte 18:93-138.

Helmers, D. L. 1991. Habitat use by migrant shorebirds and invertebrate availability in a managed wetland complex. M.S. Thesis. University of Missouri, Columbia, MO, USA.

Henderson, S. F., N. E. Latourette, and K. S. Larourette. 1916. Correspondence of the reverend Ezra Fisher. Pioneer missionary of the American Baptist Home Mission Society in Indiana, Illinois, Iowa and Oregon. Oregon Historical Quarterly 17:267-339,431468.

Henry, A. 1897. The Columbia and Willamette tour, 1814. p. 781824. In E. Coues (ed.) New Light on the Early History of the Greater Northwest: the Manuscript Journals of Alexander Henry, Fur Trader of the Northwest Company, and of David Thompson, Official Geographer and Explorer of the Same Company, 17991814; Exploration and Adventure Among the Indians on the Red, Saskatchewan, Missouri, and Columbia Rivers, volume 2. Ross and Haines, Inc., Minneapolis, MN, USA.

Hines, G. 1850. A Voyage Around the World: with a History of the Oregon Mission: and Notes of Several Years Residence on the Plains Bordering the Pacific Ocean: Comprising an Account of
Interesting Adventures Among the Indians West of the Rocky Mountains. George H. Derby and Company, Buffalo, NY, USA.

Holland, D. C. 1994. The western pond turtle: habitat and history. U.S. Department of Energy, Bonneville Power Administration, Portland, OR, USA.

Howison, N. M. 1913. Report of lieutenant Neil M. Howison on Oregon, 1846. Oregon Historical Quarterly 14:1-60.

Hulse, D., A. Branscomb, J. Giocochea-Duclos, S. Gregory, L. Ashkenas, P. Minear, S. Payne, D. Richey, H. Dearborn, J. Christy, E. Alverson, and M. Richmond. 1998. Willamette River Basin Planning Atlas, first edition. Pacific Northwest Ecosystem Research Consortium, Institute for a Sustainable Environment, University of Oregon, Eugene, OR, USA.

Jackson, P. L. and A. J. Kimerling. 1993. Atlas of the Pacific Northwest. Oregon State University Press, Corvallis, OR, USA.

Jacobs, M. 1945. Kalapuya texts. University of Washington Publications in Anthropology 11, Seattle, WA, USA.

Johannessen, C. J., W. A. Davenport, A. Millet, and S. McWilliams. 1971. The vegetation of the Willamette Valley. Annals of the Association of American Geographers 61:286-302.

Johnson, O. B. 1880. List of the birds of the Willamette Valley, Oregon. American Naturalist 14:485-491,635-641.

Johnson, J. 1993. Fieldnotes: western Oregon, winter 1992-93. Oregon Birds 19:86-88.

Kantrud, H. A. 1986. Effects of vegetation manipulation on breeding waterfowl in prairie wetlands-a literature review. U.S. Fish and Wildlife Service, Jamestown, ND, USA. Technical Report 3.

Kantrud, H. A., J. B. Millar, and A. G. van der Valk. 1989. Vegetation of wetlands of the prairie pothole region. p. 132-187. In A. van der Valk (ed.) Northern Prairie Wetlands. Iowa State University Press, Ames, IA, USA.

Kendall, T. S. 1935. T. S. Kendall's letter on Oregon agriculture. Agricultural History 9:188-197.

Landers, D., A. Fernald, and C. Andrus. 2002. Off-channel habitats. p. 24-25. In D. Hulse, S. Gregory, and J. Baker (eds.) Willamette River Basin: Trajectories of Environmental and Ecological Change, a Planning Atlas. OSU Press, Corvallis, OR, USA.

Law, G. 1887. The game birds of Oregon. American Field 28:174175.

Lee, J. 1916. Diary of Reverend Jason Lee. Oregon Historical Quarterly 17:240-266,397-430.

Lynch, J. J. 1941. The place of burning in management of Gulf Coast wildlife refuges. Journal of Wildlife Management 5:454457.

Maizel, M., R. D. White, S. Gage, L. Osborne, R. Root, S. Stitt, and G. Muehlbach. 1998. Historical interrelationships between population settlement and farmland in the conterminous United States, 1790 to 1992. p. 5-12. In T. D. Sisk (ed.) Perspectives on the land-use history of North America: a context for understanding our changing environment. U.S. Geological Survey, Biological Resources Division, Springfield, VA, USA. USGS/BRD/BSR1998-0003.

Marshall, D. B., M. G. Hunter, and A. L. Contreras. 2001. Birds of Oregon: A General Reference. http://osu.orst.edu/pubs/birds/bogr/ index.htm.

Martin, A. C. and F. M. Uhler. 1939. Food of game ducks in the United States and Canada. U.S. Department of Agriculture, Washington, DC, USA. Technical Bulletin No. 634.

McLeod, A. 1961. Journal of a hunting expedition to the southward of the Umpqua. p. 175-219. In K. G. Davie (ed.) Peter Skene Ogden's Snake Country Journal. Hudson Bay Record Society, London, UK, No. 23.

Miller, G. R. 1999. The great Willamette flood of 1861. Oregon Historical Quarterly 100:183-212.

Mills, H. A. 1882. In the Wahlamet valley of Oregon. Harper's New Monthly Magazine 65:764-771.

Minto, J. 1908. From youth to age as an American. Oregon Historical Quarterly 9:127-172.

Mitsch, W. J. and J. G. Gosselink. 2000. Wetlands, third edition. John Wiley and Sons, Inc., New York, NY, USA.

Morlan, J. C. 2000. Summary of current status and health of Oregon's freshwater wetlands. p. 45-52. In Oregon State of En- 
vironment Report 2000. Division of State Lands, Salem, OR, USA.

Morlan, J. C. and D. Peters. 1999. Oregon study confirms continued freshwater wetland losses. National Wetlands Newsletter 21(3):1.

Murphy, J. M. 1879. Rambles in North-western America from the Pacific Ocean to the Rocky Mountains. Chapman and Hall, London, UK.

Nash, W. 1882. Two Years in Oregon. D. Appleton and Company, New York, NY, USA.

National Research Council. 1992. Restoration of Aquatic Ecosystems: Science, Technology, and Public Policy. National Academy Press, Washington, DC, USA.

Nehls, H. B. 1994. Oregon shorebirds: their status and movements. Wildlife Diversity Program, Oregon Department of Fish and Wildlife, Portland, OR, USA. Technical Report 94-1-02.

Nelson, J. C., R. E. Sparks, L. DeHann, and L. Robinson. 1998. Presettlement and contemporary vegetation patterns along two navigation reaches of the Upper Mississippi River. p. 51-60. In T. D. Sisk (ed.) Perspectives on the land-use history of North America: a context for understanding our changing environment. U.S. Geological Survey, Biological Resources Division. USGS/ BRD/BSR-1998-0003.

Newberry, J. S. 1857. Chapter II: Report upon the birds. p. 73-100. In Reports of Explorations and Surveys to Ascertain the Most Practicable and Economical Route for a Railroad from the Mississippi River to the Pacific Ocean 1854-55, volume 6, part IV, zoological report no. 2. Beverly Tucker, Washington, DC, USA.

Noss, R. F., E. T. LaRoe III, and J. M. Scott. 1995. Endangered ecosystems of the United States: a preliminary assessment of loss and degradation. National Biological Service, Washington, DC, USA. Biological Report 28.

Oetter, D. R., W. B. Cohen, M. Berterretche, T. K. Maiersperger, and R. E. Kennedy. 2000. Land cover mapping in an agricultural setting using multiseasonal Thematic Mapper data. Remote Sensing of Environment 76:139-155.

Oregon State Planning Board. 1938. Land development in Oregon: through flood control, drainage, and irrigation. Oregon State Planning Board, Salem, OR, USA.

Oregon Wetlands Joint Venture. 2001. Oregon Wetlands Newsletter. Oregon Wetlands Joint Venture, Lake Oswego, OR, USA.

Palmer, J. 1983. Journal of Travels Over the Rocky Mountains, to the Mouth of the Columbia River, Made During the Years 1845 and 1846. Ye Galleon Press, Fairfield, WA, USA

Parker, S. 1967. Journal of an Exploring Tour Beyond the Rocky Mountains, Under the Direction of the A.B.C.F.M. Performed in the Years 1835, '36, and '37, Containing a Description of the Geography, Geology, Climate, and Productions, and the Number, Manners, and Customs of the Natives, with a Map of Oregon Territory. Ross and Haines, Minneapolis, MN, USA.

Parsons, R. B., C. A. Balster, and A. O. Ness. 1970. Soil development and geomorphic surfaces, Willamette Valley, Oregon. Soil Science Society of America Proceedings 34:485-491.

Pater, D. E., S. Bryce, T. D. Thorson, J. Kagan, C. Chappell, J. Omernik, S. Azevedo, and A. J. Woods. 1997. Ecoregions of western Washington and Oregon. U.S. Environmental Protection Agency, Corvallis, OR, USA.

Peale, T. R. 1858. United States Exploring Expedition During the Years 1838, 1839, 1840, 1841, 1842, Under the Command of Charles Wilkes, U.S.N., Mammalogy and Ornithology, volume 8. C. Sherman and Son, Philadelphia, PA, USA.

Pennak, R. W. 1989. Freshwater Invertebrates of the United States: Protozoa to Mollusca. John Wiley and Sons, Inc., New York, NY, USA.

Perrine, F. S. 1924. Early days on the Willamette. Oregon Historical Quarterly 4:295-312.

Poesch, J. 1961. Titian Ramsay Peale and his Journals of the Wilkes Expedition. American Philosophical Society, Philadelphia, PA, USA.

Pope, A. L. 1895-1896. A list of the birds of Oregon. Oregon Naturalist 2:141-143,157-160; 3:1-3.

Pope, A. L. 1896. Notes on winter birds of Yamhill Co., Oregon. Oregon Naturalist 3:151-153.

Prince, H. 1997. Wetlands of the American Midwest: a Historical
Geography of Changing Attitudes. University of Chicago Press, Chicago, IL, USA.

Prill, A. G. 1895. Winter birds of Linn County, Oregon. Oölogist 12:47-49.

Robbins, W. G. 1997. Landscapes of Promise: the Oregon Story 1800-1940. University of Washington Press, Seattle, WA, USA.

Rutkosky, F. W. 1978. Bibliography on the effects of prescribed burning and mammal and waterfowl utilization of wetlands: annotated literature search with selected abstracts. U.S. Fish and Wildlife Service, Annapolis, MD, USA.

Samson, F. and F. Knopf. 1994. Prairie conservation in North America. BioScience 44:418-421.

Sanzenbacher, P. M. and S. M. Haig. 2002a. Residency and movement patterns of wintering Dunlin in the Willamette Valley of Oregon. Condor 104:271-280.

Sanzenbacher, P. M. and S. M. Haig. 2002b. Regional fidelity and movement patterns of wintering Killdeer in an agricultural landscape. Waterbirds 25:16-25.

Schlichtemeier, G. 1967. Marsh burning for waterfowl. Proceedings of the Annual Tall Timbers Fire Ecology Conference 6:41-46.

Scott, L. M. 1923. John Work's journey from Fort Vancouver to Umpqua River and return, in 1834. Oregon Historical Quarterly 24:228-268.

Sedell, J. R. and J. L. Froggatt. 1984. Importance of streamside forests to large rivers: the isolation of the Willamette River, Oregon, U.S.A. from its floodplain by snagging and streamside forest removal. Verhandlungen Internationale Vereinigen Limnologie 22:1828-1834.

Shafer, J. 1909. Documents relative to Warre and Vavasour's military reconnaisance in Oregon, 1845-6. Oregon Historical Quarterly $1: 1-100$.

Shapiro and Associates, Inc. 1980. Humboldt Bay wetlands review and baylands analysis, 3 volumes. U.S. Army Corps of Engineers, San Francisco, CA, USA.

Singh, J. S. and M. C. Joshi. 1979. Primary production. p. 197-218. In R. T. Coupland (ed.) Grassland Ecosystems of the World: Analysis of Grasslands and Their Uses. International Biological Programme 18, Cambridge University Press, Cambridge, UK.

Sisk, T. D. 1998. Toward a land-use history of North America: a context for understanding environmental change. p. 1-4. In T. D. Sisk (ed.) Perspectives on the land-use history of North America: a context for understanding our changing environment. U.S. Geological Survey, Biological Resources Division, Springfield, VA, USA. USGS/BRD/BSR-1998-0003.

Smith, L. M., J. A. Kadlec, and P. V. Fonnesbeck. 1984. Effects of prescribed burning on nutritive quality of marsh plants in Utah. Journal of Wildlife Management 48:285-288.

Smith, L. M., R. L. Pederson, and R. M. Kaminski. 1989. Habitat Management for Migrating and Wintering Waterfowl in North America. Texas Tech University Press, Lubbock, TX, USA.

Stone, K. L. 1994. Shorebird habitat use and response to burned marshes during spring migration in south-central Kansas. M.S. Thesis. Colorado State University, Fort Collins, CO, USA.

Storm, R. M. 1941. Effect of the white man's settlement on the wild animals in the Mary's River Valley. M.S. Thesis. Oregon State University, Corvallis, OR, USA.

Svart, L. M. 1970. Field burning in the Willamette Valley: a case study of environmental quality control. M.S. Thesis. University of Washington, Seattle, WA, USA.

Taft, O. W., S. M. Haig, and C. Kiilsgaard. 2003 (in press). Use of radar remote sensing (RADARSAT) to map winter wetland habitat for shorebirds in an agricultural landscape. Environmental Management 31:(in press).

Takekawa, J. Y. and N. Warnock. 2000. Long-billed Dowitcher (Limnodromus scolopaceus). p. 1-19. In A. Poole, P. Stettenheim, and F. Gill (eds.) The Birds of North America, No. 493. The Birds of North America, Inc., Philadelphia, PA, USA.

Thomas, D. W. 1983. Habitat changes in the Columbia river estuary since 1868. Columbia River Estuary Taskforce, Astoria, OR, USA.

USDA Soil Conservation Service. 1977. Willamette Valley drainage guide. U.S. Department of Agriculture, Soil Conservation Service, Portland, OR, USA. 
U.S. Department of Agriculture. 2000. Soil Survey Geographic Data Base (SSURGO) of Oregon. USDA, Natural Resources Conservation Service, Washington, DC, USA.

U.S. Fish and Wildlife Service, and Canadian Wildlife Service. 1994. 1994 update to the North American Waterfowl Management Plan: expanding the commitment. U.S. Fish and Wildlife Service, Washington, DC, USA.

Victor, F. F. 1872. All Over Oregon and Washington, Observations on the Country, Its Scenery, Soil. John H. Carmany and Company, San Francisco, CA, USA.

Vileisis, A. 1997. Discovering the Unknown Landscape: a History of America's Wetlands. Island Press, Washington, DC, USA

Vogl, R. J. 1973. Effects of fire on the plants and animals of a Florida wetland. American Midland Naturalist 89:334-347.

Ward, P. 1968. Fire in relation to waterfowl habitat of the Delta marshes. Proceedings of the Annual Tall Timbers Fire Ecology Conference 8:255-268.

Weller, M. W. 1987. Freshwater Marshes: Ecology and Wildlife Management. University of Minnesota Press, Minneapolis, MN, USA.

Whitlock, C. and M. A. Knox. 2002. Prehistoric burning in the Pacific Northwest. p. 195-231. In T. R. Vale (ed.) Fire, Native Peoples, and the Natural Landscape. Island Press, Washington, DC, USA.

Wilkes, C. M. 1911. Document-report on the territory of Oregon. Oregon Historical Quarterly 3:269-299.

Willamette Restoration Initiative. 2001. Restoring a river of life: the
Willamette Restoration Strategy, recommendations for the Willamette Basin supplement to the Oregon Plan for Salmon and Watersheds. Counterpoint Consulting, Portland, OR, USA.

Williams, I. A. 1914. The drainage of farm lands in the Willamette and tributary valleys of Oregon, the mineral resources of Oregon. The Oregon Bureau of Mines and Geology, Corvallis, OR, USA

Wilson, M. V. 1998. Wetland prairie. Willamette Valley Basin Recovery Plan, part 1. U.S. Fish and Wildlife Service, Portland, OR, USA.

Winsor, R. A. 1987. Environmental imagery of the wet prairie of east central Illinois, 1820-1920. Journal of Historical Geography 13:375-397

Woodcock, A. R. 1902. Annotated list of the birds of Oregon. Oregon Agricultural Experimental Station Bulletin 68:1-118.

Woodward, D. G., M. W. Gannett, and J. J. Vaccaro. 1998. Hydrogeologic framework of the Willamette lowland aquifer system, Oregon and Washington regional aquifer-system analysis-PugetWillamette lowland. U.S. Geological Survey, Washington, DC, USA. Professional Paper 1424-B.

Wyeth, N. J. 1969. The Journals of Captain Nathaniel J. Wyeth, with the Wyeth Monograph on Pacific Northwest Indians Appended. Ye Galleon Press, Fairfield, WA, USA.

Zenk, H. 1976. Contributions to Tualatin Ethnography: Subsistence and Ethnobiology. M.S. Thesis, Portland State University, Portland, OR, USA.

Manuscript received 18 April 2002; revisions received 16 August 2002 and 11 October 2002; accepted 18 November 2002. 